\title{
Determination of Theobromine and Caffeine in Theobroma cacao Husk from Ethanolic Extract by GC-MS after CC Separation
}

\author{
José González1*, Max Monan², Julio Perez³ , Enrique Gómez4, Damaris De La C. Salgado4, \\ Danae Pérez ${ }^{4}$
}

${ }^{1}$ Faculty of Technical Sciences, University of Pedagogical Sciences, Havana, Cuba

${ }^{2}$ ARVARNAM, Martinica, France

${ }^{3}$ National Center of Toxicology, Military Hospital “Dr. Carlos J. Finlay”, Havana, Cuba

${ }^{4}$ Institute of Pharmacy and Foods, Havana University, Havana, Cuba

Email: ^jgyaque60@gmail.com

How to cite this paper: González, J., Monan, M., Perez, J., Gómez, E., De La C. Salgado, D. and Pérez, D. (2019) Determination of Theobromine and Caffeine in Theobroma cacao Husk from Ethanolic Extract by GC-MS after CC Separation. Open Access Library Journal, 6: e5771.

https://doi.org/10.4236/oalib.1105771

Received: September 9, 2019

Accepted: November 23, 2019

Published: November 26, 2019

Copyright $\odot 2019$ by author(s) and Open Access Library Inc.

This work is licensed under the Creative Commons Attribution International License (CC BY 4.0).

http://creativecommons.org/licenses/by/4.0/

\begin{abstract}
After CC separation of 21 samples from Theobroma cacao Husk was analyzed by GC-MS, from ethanolic extract at $90 \%$ was recovered a solid residue of $1 \mathrm{~g}$ after several days on the table of the Lab. This main residue $(300 \mathrm{mg}$ ) was analyzed after successive separations with mixtures of $\mathrm{CHCl}_{3}: \mathrm{MeOH}(7: 3)$ and $\mathrm{CHCl}_{3}: \mathrm{MeOH}$ (5:5) in CC using Sílica Gel G 60-120 Mesh. All samples were analyzed by TLC on silica gel with fluorescent indicator $254 \mathrm{~nm}$ on aluminum cards (layer thickness $0.2 \mathrm{~mm})(10 \times 20 \mathrm{~cm})$ using $\mathrm{CHCl}_{3}: \mathrm{MeOH}$ : n-propanol: water (5:6:1:4) as eluent (v/v/v). The presence of Caffeine (CF) and Theobromine (TB) was confirmed after several analyses of the samples by their characteristic fragmentation pattern but nevertheless was found the presence of Theophylline.
\end{abstract}

\section{Subject Areas}

Bioengineering, Biotechnology

\section{Keywords}

Theobroma cacao, Caffeine, Theobromine, GC-MS, CC, TLC

\section{Introduction}

Total production of cacao bean is estimated worldwide to be approximately 4.0 million tons in 2013 , with a value about $\$ 12$ billion. Residues or wastes from the cacao processing industry consist of cacao pod shell, husk, pulp/mucilage, and 
hull, which account for a high proportion, approximately $85 \%$ by fresh weight of total cacao pod mass, in which the annual worldwide amount of cacao pod husk is estimated to be about 55 million tons, which is equal to 13 times the total amount of cacao bean. Therefore, cacao pod husk needs to be exploited to produce high-value-added products and this waste has been considered as an abundant, inexpensive, and renewable source of caffeine and theobromine, which exhibits stimulatory effects on the central nervous, gastrointestinal, cardiovascular, renal, and respiratory systems [1].

Native to lowland rainforests of the Amazon and Orinoco river basins, cacao is grown commercially in the New World tropics as well as western Africa and tropical Asia. Its seeds, called cocoa beans, are processed into cocoa powder, cocoa butter, and chocolate [2].

Residues or wastes from the cacao processing industry consist of cacao pod shell, husk, pulp/mucilage, and hull, which account for a high proportion, approximately $85 \%$ by fresh weight of total cacao pod mass, in which the annual worldwide amount of cacao pod husk is estimated to be about 55 million tons, which is equal to 13 times the total amount of cacao bean [3].

The consumption of cocoa/chocolate 1) increases plasma antioxidant capacity, 2) diminishes platelet function and inflammation, and 3) decreases diastolic and systolic arterial pressures. Data currently available indicate that daily consumption of cocoa-rich chocolate (rich in polyphenols) may at least partially lower cardiovascular disease risk. Further studies are required in order to establish the bioavailability and mechanisms of action of bioactive compounds in chocolate [4].

Methylxanthines, theobromine and caffeine are used as analgesics, diet aids, and cold/flu remedies in numerous popular carbonated drinks. They are also the main compounds found in tea, coffee, sodas, chocolate, and various energy drinks. More than 120,000 tons of caffeine is consumed worldwide annually [5].

The analysis of theobromine and caffeine in foods, biological fluids, environmental samples, plants, and water, was provided with different instrumental methods, such as high-performance liquid chromatography (HPLC) [6], gas chromatography-mass spectrometry-flame ionization detection (GC-MS-FID) [7], Fourier transform-infrared spectrophotometry (FT-IR) [8], near-infrared spectroscopy [9], UV-Vis spectrophotometry [10], FT-Raman spectrometry [11], and capillary electrophoresis (CE) [12].

The aim of this research was to determine the presence of theobromine, caffeine and theophylline in a solid sample from ethanolic extracts at $90 \%$ from Theobroma cacao husk after carried out the insoluble solid by CC and running by CG-MS the 21 samples recovered after CC elution.

\section{Materials and Methods}

\subsection{Sample Collection and Processing:}

The sample was the husk of cocoa bean after its separation from the fruits. It was 
supplied in 2018 by the Chocolate Factory located in Baracoa, Guantánamo Province, Cuba. After the collection the husks were packet in nylon bags without elimination of foreign matters. The material was grounded in a high-speed hammer mill. The sample keeps its brown color (Figure 1) and a very nice chocolate's smell.

\subsection{Extract Preparation}

The extracts were prepared with the ground material (60 g) without screen extracted in a Soxhlet apparatus with $675 \mathrm{~mL}$ of ethanol at $90 \%$ for 20 hours. The ethanolic extracts were concentrated and evaporated under vacuum to $200 \mathrm{~mL}$ at $120 \mathrm{rpm}$, a temperature of $70^{\circ} \mathrm{C}$ and 500 mbar.

\subsection{Separation of the Samples}

After extraction the ethanolic extract was kept on the Lab table during few days. A solid yellowish-green residue $(1 \mathrm{~g})$ appeared on the bottom of the recipient and was recovered by decantation (Figure 2 ).

$300 \mathrm{mg}$ of this solid was then passed thought a CC $(31.5 \mathrm{~cm} \times 1.5 \mathrm{~cm} \phi)$ (Figure 3) using as stationary phase Sílica Gel G $60-120$ Mesh (Merck) and as mobile phase $25 \mathrm{~mL}$ of a mixture of $\mathrm{CHCl}_{3}: \mathrm{MeOH}$ (7:3). After that point, was added successively, $20 \mathrm{~mL}$ of pure $\mathrm{MeOH}, 30 \mathrm{~mL}$ of $\mathrm{CHCl}_{3}: \mathrm{MeOH}(7: 3) ; 10 \mathrm{~mL}$ of $\mathrm{MeOH}$ and finally, $20 \mathrm{ML}$ of $\mathrm{CHCl}_{3}: \mathrm{MeOH}$ (5:5). The column was cleaned first with chloroform.

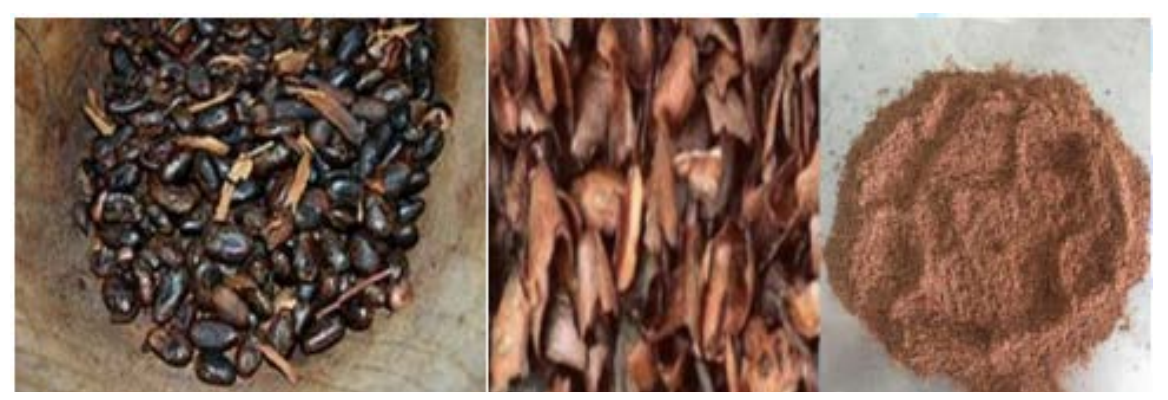

Figure 1. Toasted cacao beans, husk and powered drug.

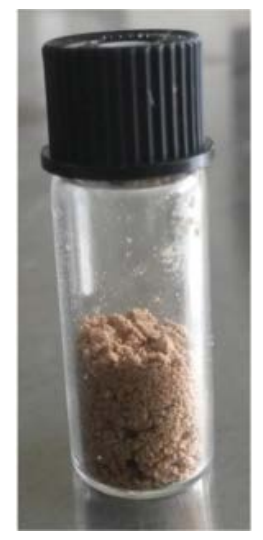

Figure 2. Solid residue from ethanolic extract of cacao husk. 


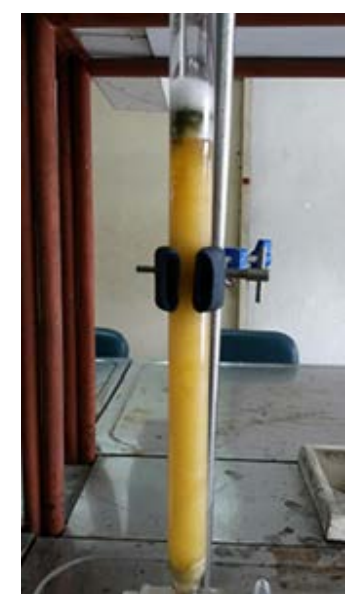

Figure 3. Chromatography column.

\subsection{Procedures, Instrumentation and Parameters}

The samples were subjected to chromatographic analysis in equipment GC/MS; brand Shimadzu QP2010, equipped with a splitter split/splitless. With a BP5 (30 $\mathrm{m} \times 0.25 \mathrm{~mm} \times 0.25$ microns) capillary column under the following chromatographic conditions: Helium gas carrier obtained by electron impact fragments to a power of $70 \mathrm{eV}$ rate of $1.2 \mathrm{~mL} / \mathrm{min}, 1: 50$ split flow and the volume of injected sample of $1 \mu \mathrm{L}$. Programmed oven temperature: initial temperature was $70^{\circ} \mathrm{C}$ with a heating ramp of $10^{\circ} \mathrm{C} / \mathrm{min}$ to $300^{\circ} \mathrm{C}$ and remained stable at this temperature for 10 minutes. Subsequently the temperature was increased at a rate of $10^{\circ} \mathrm{C} /$ minute to $300^{\circ} \mathrm{C}$ for a total time of 78 minutes with an injector temperature $250^{\circ} \mathrm{C}$ and the interface temperature $300^{\circ} \mathrm{C}$. The compounds were analyzed using GC/MS NIST21 and NIST107 library and having into account the results obtained after phytochemical screening according with González et al., 2017. Silylation agent was $\mathrm{N}, \mathrm{O}$-bis(trimethylsilyl) trifluoroacetamide (BSTFA), CAS 25561-30-2, Lot: 0901-1 Macherey-Nagel GmbH \& C. KG.

\section{Results and Discussion}

Twenty-one samples were recovered from the CC after solid insoluble sample separation (Figure 4). Five fractions $(1-5)$ were obtained using a mixture of $\mathrm{CHCl}_{3}: \mathrm{MeOH}$ (7:3). Successively were added pure $\mathrm{MeOH}$ (A-D), alternating with $\mathrm{CHCl}_{3}: \mathrm{MeOH}(7: 3)\left(6\right.$ - 11), $\mathrm{MeOH}(\mathrm{E}-\mathrm{F})$ and $\mathrm{CHCl}_{3}: \mathrm{MeOH}(5: 5)(12$ 15). In general, were taken 21 samples of $5 \mathrm{~mL} ; 15$ of them from the mixture of $\mathrm{CHCl}_{3}: \mathrm{MeOH}$ and six from pure $\mathrm{MeOH}$.

The twenty-one samples after running by CG-MS showed a general chromatogram as shown in Figure 5. The most prominent peaks are between 25 and 40 minutes of retention time with some few exceptions.

The automatically comparison of the results with NIST 21 and NIST $107 \mathrm{Li}-$ braries allow us to tentatively suggest the presence of caffeine and theobromine in all samples but with different retention times like is presented in Table 1. In all cases caffeine appear firstly than theobromine. The first Methylxanthine was 


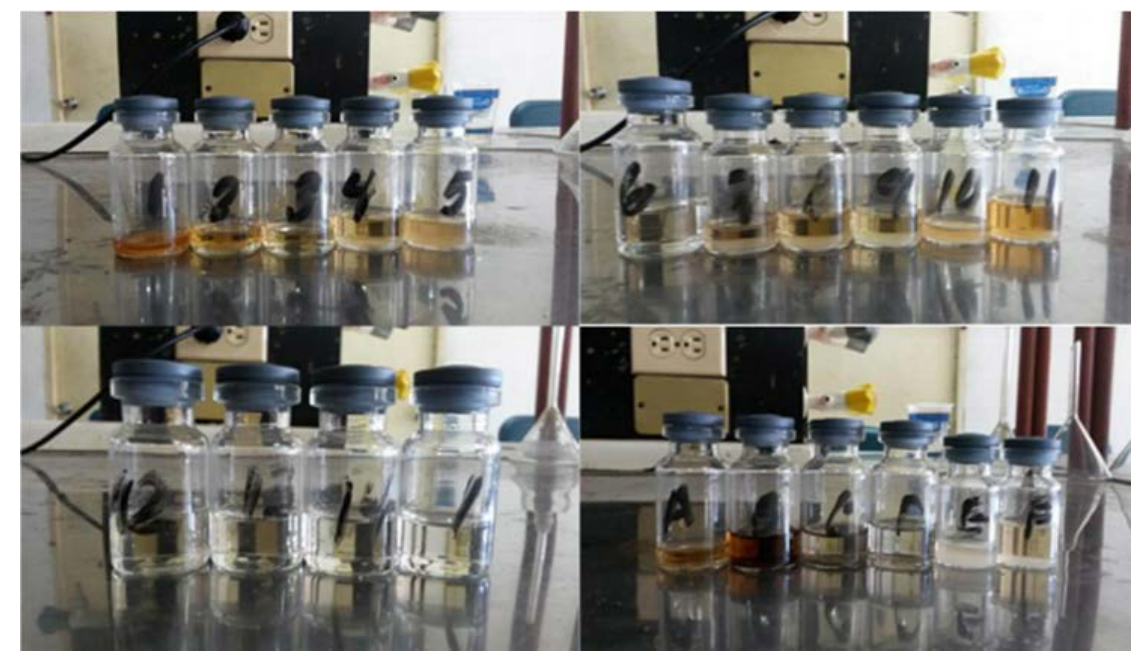

Figure 4. Collected samples from CC after insoluble solid separation.

Table 1. Retention times of caffeine and theobromine in each sample.

\begin{tabular}{|c|c|c|c|}
\hline Sample & Caffeine & Theobromine & Manually predominant compound \\
\hline 1 & 29.490 & 29.695 & Caffeine \\
\hline 2 & 29.245 & 29.695 & Theobromine \\
\hline 3 & 29.235 & 29.865 & Theobromine \\
\hline 4 & 29.230 & 29.820 & Theobromine \\
\hline 5 & 29.270 & 29.665 & Theobromine \\
\hline 6 & 29.265 & 29.695 & Theobromine \\
\hline 7 & 29.250 & 29.705 & Theobromine \\
\hline 8 & 29.260 & 29.690 & Theobromine \\
\hline 9 & 29.260 & 29.880 & Theobromine \\
\hline 10 & 29.255 & 29.710 & Theobromine \\
\hline 11 & 29.260 & 29.840 & Theobromine \\
\hline 12 & 28.250 & 29.890 & Theobromine \\
\hline 13 & 29.250 & 30.005 & Theobromine \\
\hline 14 & 29.240 & 29.905 & Theobromine \\
\hline 15 & 29.235 & 29.800 & Theobromine \\
\hline A & 29.260 & 29.775 & Uncertain \\
\hline B & 29.265 & 29.610 & Uncertain \\
\hline $\mathrm{C}$ & 29.240 & 29.750 & Theobromine \\
\hline $\mathrm{D}$ & 29.245 & 29.710 & Theobromine \\
\hline $\mathrm{E}$ & 29.260 & 29.625 & Theobromine \\
\hline F & 29.245 & 29.915 & Theobromine \\
\hline
\end{tabular}

between $29.230 \mathrm{~min}$ and $29.270 \mathrm{~min}$ of retention time, while the second one was between 29.610 and 30.005 min of retention time. 

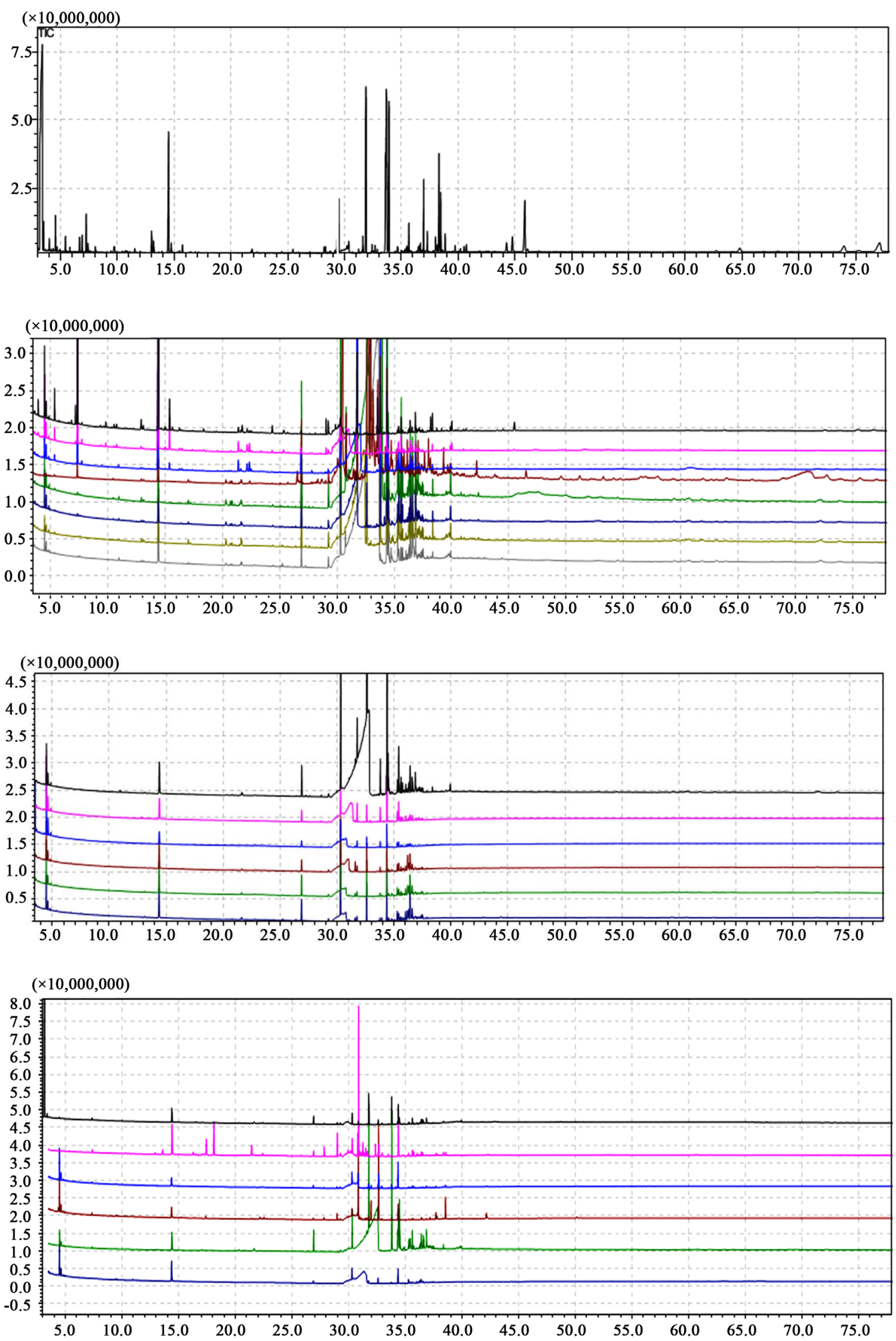

Figure 5. Current chromatograms of the samples (from top to down: $1 ; 2$ - 9; 10 - 15; A-F). 

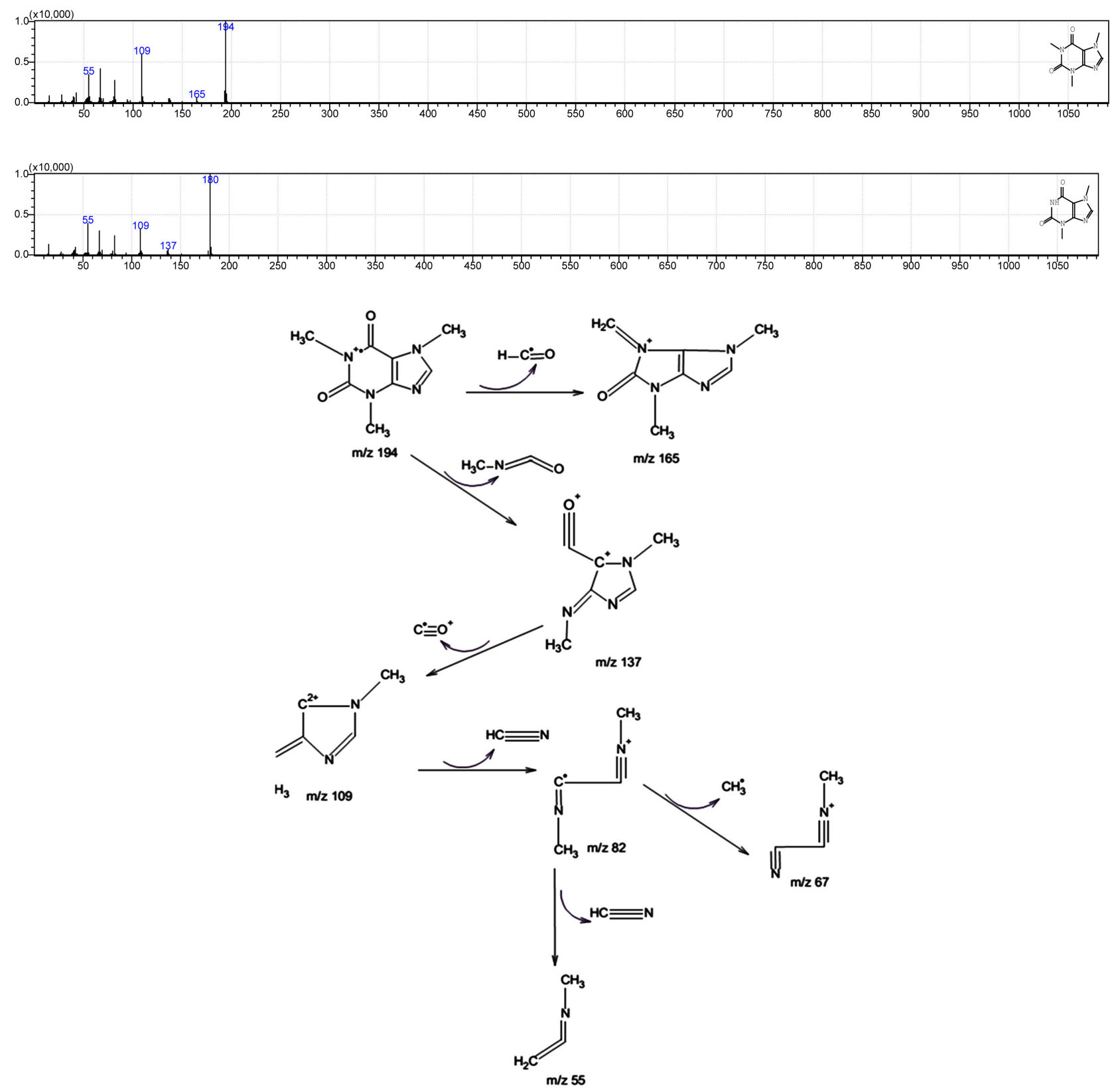

Figure 6. Fragmentation pattern of theobromine and caffeine.

Manually registration of each compound showed a big difference, because using this kind of selective search each sample had another behavior. Sample 1 showed the presence of caffeine at 29.485 minutes of retention time, according to NIST 107 Library with a coincidence of $91 \%$ - 93\%, while in sample 2 the coincidence was only $65 \%$ according to NIST 21 Library to theobromine as a predominant compound.

No theophylline was detected in this research. According to Vázquez-Ovando in 2016 [13], the main alkaloid in cacao is theobromine, but both compounds can coexist because of the presence of the theobromine sintase enzyme. Accumulation of purine alkaloids is dependent on the presence of substrate specificity 
of N-metil-transferase.

Using LC-ESI-MS, according to [5], the researchers found that both compound (caffeine and theobromine) had the same fragmentation pattern in the peak $\mathrm{m} / \mathrm{z}$ 137. As discussed in [14], using different extraction methods and HPLC, reported that both alkaloids had the same fragmentation pattern and declare that is possible to find out the superposition of theobromine, theophylline and caffeine as a mixture.

Figure 6 shows the fragmentation pattern of both chemical components and the fragmentation pattern of caffeine according to [15] and the data from our research group in this investigation.

\section{Conclusion}

This study was an exploratory and valuable assessment for further studies. The findings from this study indicated that cacao pod husk had high contents of caffeine and theobromine, but low or none contents of theophylline. Therefore, the use of these extraction and purification conditions for effective exploitation of theobromine and caffeine from cacao pod husk is a promising and sustainable trend. In further studies, it is necessary to determine the biological variability of theobromine and caffeine in cacao pod husk samples, as well as produce theobromine-caffeine enriched powder and evaluate its biological activity in various models for potential application in the medical, nutraceutical and pharmaceutical industries.

\section{Conflicts of Interest}

The authors declare no conflict of interest.

\section{References}

[1] FAOSTAT (2017) Cocoa Beans Production in 2016, Crops/World Regions/Cocoa Beans/Production Quantity from Pick Lists. United Nations Food and Agriculture Organization, Statistics Division (FAOSTAT).

[2] Cook, L.R. (2018) Cacao Tree. Encyclopedia Britannica.

[3] Nguyen, V.T. and Nguyen, N.H. (2017) Proximate Composition, Extraction, and Purification of Theobromine from Cacao Pod Husk (Theobroma cacao L.). Technologies, 5, 14. https://doi.org/10.3390/technologies5020014

[4] Gómez-Juaristi, M., González-Torres, L., Bravo, L., Vaquero, M.P., Bastida, S. and Sánchez-Muniz, F.J. (2011) Efectos beneficiosos del chocolate en la salud cardiovascular. Nutricion Hospitalaria, 26, 289-292.

[5] Al-Qaim, F., Yuzir, A. and Mussa, Z. (2018) Determination of Theobromine and Caffeine in Some Malaysian Beveragesby Liquid Chromatography-Time of Flight Mass Spectrometry. Tropical Journal of Pharmaceutical Research, 17, 529-535. https://doi.org/10.4314/tipr.v17i3.20

[6] Ali, H.S., Abdullah, A.A., Pınar, P.T., Yardım, Y. and Şentürk, Z. (2017) Simultaneous Voltammetric Determination of Vanillin and Caffeine in Food Products Using an Anodically Pretreated Boron-Doped Diamond Electrode: Its Comparison with HPLC-DAD. Talanta, 170, 384-391. 
https://doi.org/10.1016/j.talanta.2017.04.037

[7] Rahim, A.A., Saad, B., Osman, H., Hashim, N., Yahya, S. and Talib, K.M. (2011) Simultaneous Determination of Diethylene Glycol, Diethylene Glycol Monoethyl Ether, Coumarin and Caffeine in Food Items by Gas Chromatography. Food Chemistry, 126, 1412-1416. https://doi.org/10.1016/j.foodchem.2010.11.121

[8] Palo, M., Kogermann, K., Genina, N., Fors, D., Peltonen, J., Heinämäki, J. and Sandler, N. (2016) Quantification of Caffeine and Loperamide in Printed Formulations by Infrared Spectroscopy. Journal of Drug Delivery Science and Technology, 34, 60-70. https://doi.org/10.1016/j.jddst.2016.02.007

[9] Zhang, X., Li, W., Yin, B., Chen, W., Kelly, D.P., Wang, X., Zheng, K. and Du, Y. (2013) Improvement of Near Infrared Spectroscopic (NIRS) Analysis of Caffeine in Roasted Arabica Coffee by Variable Selection Method of Stability Competitive Adaptive Reweighted Sampling (SCARS). Spectrochimica Acta Part A, 114, 350-356. https://doi.org/10.1016/j.saa.2013.05.053

[10] Shehata, A.B., Rizk, M.S. and Rend, E.A. (2016) Certification of Caffeine Reference Material Purity by Ultraviolet/Visible Spectrophotometry and High-Performance Liquid Chromatography with Diode-Array Detection as Two Independent Analytical Methods. Journal of Food and Drug Analysis, 24, 703-715. https://doi.org/10.1016/j.jfda.2016.06.009

[11] Armenta, S., Garrigues, S. and de la Guardia, M. (2005) Solid-Phase FT-Raman Determination of Caffeine in Energy Drinks. Analytica Chimica Acta, 547, 197-203. https://doi.org/10.1016/j.aca.2005.05.032

[12] Meinhart, A.D., Bizzotto, C.S., Ballus, C.A., Prado, M.A., Bruns, R.E., Filho, J.T. and Godoy, H.T. (2010) Optimisation of a CE Method for Caffeine Analysis in Decaffeinated Coffee. Food Chemistry, 120, 1155-1161.

https://doi.org/10.1016/j.foodchem.2009.11.048

[13] Alfredo, V.-O., Ovando-Medina, I., Adriano-Anaya, L., Betancur-Ancona, D. and Salvador-Figueroa, M. (2016) Alcaloides y polifenoles del cacao, mecanismos que regulan su biosíntesis y sus implicaciones en el sabor y aroma. Archivos Latinoamericanos de Nutrición, 66, 239-254.

[14] Cuéllar García Oscar Andrés (2010) Obtencion del extracto polar etanol: Agua (1:1) de la cascara de cacao y evaluacion de su actividad antibacteriana. Documento presentado como requisito parcial para optar al título de tecnólogo químico. Universidad Tecnológica de Pereira.

[15] Wang, L.J. and Weller, C. (2006) Recent Advances in Extraction of Nutraceuticals from Plants. Trends in Food Science \& Technology, 17, 300-312.

https://doi.org/10.1016/j.tifs.2005.12.004 